\title{
Exercise and obesity
}

\author{
Tracy J. Horton* and James O. Hill \\ Center for Human Nutrition, Department of Pediatrics, University of Colorado Health Services Center, Denver, \\ Colorado 80231, USA
}

Obesity is a condition of excess body fat. While genetic factors can influence the body fatness of an individual, environmental factors, promoting a high energy intake and low energy expenditure (EE), appear to be driving the high prevalence of obesity in many countries (Danforth, 1985; Brownell \& Wadden, 1992; Van Itallie, 1996). A low level of physical activity can contribute to a low total EE and is thought to promote positive energy balance and weight gain (Flatt, 1987; James, 1995). This is supported by crosssectional data which show that individuals and groups characterized by a low level of physical activity have a greater body weight and body fat content compared with their more active counterparts (Schulz \& Schoeller, 1994; Roberts, 1995; Ryan et al. 1996). A low activity level, however, could be a consequence rather than a cause of obesity. Nevertheless, longitudinal data also suggest that a low level of physical activity is associated with an increased risk of weight gain (Roberts et al. 1988; Griffiths et al. 1990; Williamson et al. 1993). Thus, regular physical exercise appears to be important in helping maintain a normal body weight and body composition.

Both metabolic and behavioural factors play a role in the development of obesity (Hill et al. 1994). The relative contributions of these factors to weight gain probably vary between individuals. Both food intake and physical activity have behavioural and metabolic components. With respect to physical activity, the behaviour relates to the quantity and type of physical activity an individual chooses to engage in, whereas the metabolic factors relate to the amount of energy expended, the pattern of fuels utilized and the hormone and metabolite changes resulting from the exercise. As yet, we have a poor understanding of how the metabolic effects of physical activity affect exercise and/or food intake behaviour. However, the metabolic response to exercise is more clearly understood. The present paper, therefore, will review the metabolic effects of exercise, specifically with respect to energy and fat metabolism, and how this may relate to the long-term control of body weight.

\section{Energy expenditure and its components}

Total daily EE $(24 \mathrm{~h}$ EE $)=$ resting metabolic rate $(\mathrm{RMR})$

+ energy cost of activity + thermic effect of food (TEF)
(+ arousal). The major component of $24 \mathrm{~h} \mathrm{EE}$ is the RMR. This generally accounts for approximately $60-75 \%$ of total expenditure (Danforth, 1985). TEF contributes about $10 \%$ to $24 \mathrm{~h} \mathrm{EE}$, while the contribution of arousal is probably very small. The energy cost of activity can be the most variable component of $24 \mathrm{~h}$ EE both from day to day and between individuals. Although the obvious consequence of planned exercise is an increase in the contribution of the energy cost of activity to daily EE, exercise may also affect other components of $24 \mathrm{~h} \mathrm{EE}$, e.g. RMR. Exercise may also have important effects on nutrient balance and, in particular, fat balance.

\section{The effect of an acute bout of exercise on energy expenditure}

The net energy cost of exercise is calculated as the increase in exercise EE above resting level. In athletes, the net energy cost of exercise can contribute as much as 3360 $16800 \mathrm{~kJ}$ to $24 \mathrm{~h}$ EE (Brouns et al. 1989 ; Schulz et al. 1992; Horton et al. 1994). This requires moderate- to highintensity activity sustained for $75 \mathrm{~min}$ to many hours. However, most individuals do not have the ability, the time or the desire to be so active. For the average person who wishes to incorporate exercise into their daily routine, the net energy cost of exercise is likely to be much lower. For moderate exercise of moderate duration, a net EE of 756$1890 \mathrm{~kJ}$ can be predicted (Table 1 ).

In addition to the net energy cost of exercise during the activity itself, EE remains elevated for a certain time period post-exercise, i.e. the excess post-exercise $\mathrm{O}_{2}$ consumption (EPOC; Gaesser \& Brooks, 1984). This is calculated as the elevation in $\mathrm{O}_{2}$ consumption, above resting level, during the post-exercise period. Much research has focused on this phenomenon as it has been suggested that EPOC could significantly increase daily EE and so help with weight loss and the prevention of weight gain (Cannon \& Einzig, 1984). With aerobic exercise, it has been shown that the degree and duration of EPOC are dependent on the intensity and duration of the exercise (Bahr et al. 1987; Gore \& Withers, 1990; Quinn et al. 1994). However, EPOC is unlikely to significantly increase $24 \mathrm{~h}$ EE for the average individual performing moderate exercise (Freedman-Aka-

\footnotetext{
Abbreviations: EE, energy expenditure; EPOC, excess post-exercise $\mathrm{O}_{2}$ consumption; FFM, fat-free mass; RMR, resting metabolic rate; TEF, thermic effect of food.

*Corresponding author: Dr T. J. Horton
} 
Table 1. Energy cost of an acute moderate exercise bout

\begin{tabular}{|c|c|c|c|}
\hline Body weight (kg) & 60 & 80 & 100 \\
\hline $\begin{array}{l}\text { Estimated RMR }{ }^{*}(\mathrm{~kJ} / \mathrm{min}) \\
\text { Exercise at } 5.0 \mathrm{MET} \text { for } 45 \mathrm{~min}\end{array}$ & $4 \cdot 2$ & 5.6 & 7.0 \\
\hline Net EE (kJ) & 756 & 1008 & 1260 \\
\hline EPOC $\dagger(k J)$ & 113 & 151 & 189 \\
\hline Potentiation of TEF $(\mathrm{kJ})$ & 63 & 63 & 63 \\
\hline Total energy $(\mathrm{kJ})$ & 932 & 1222 & 1512 \\
\hline \multicolumn{4}{|l|}{ Exercise at $10.0 \mathrm{MET}$ at $30 \mathrm{~min}$} \\
\hline $\begin{array}{l}\text { Net EE }(\mathrm{kJ}) \\
\text { EPOC } \dagger(\mathrm{kJ})\end{array}$ & $\begin{array}{r}1008 \\
151 \\
63\end{array}$ & $\begin{array}{r}1512 \\
227\end{array}$ & $\begin{array}{r}1890 \\
284\end{array}$ \\
\hline $\begin{array}{l}\text { Potentiation of TEF } \ddagger(k J) \\
\text { Total energy }(k J)\end{array}$ & $\begin{array}{r}63 \\
1222\end{array}$ & $\begin{array}{r}63 \\
1802\end{array}$ & $\begin{array}{r}63 \\
2237\end{array}$ \\
\hline
\end{tabular}

RMR, resting metabolic rate; $1 \mathrm{MET}, \mathrm{O}_{2}$ consumption at rest; $E E$, energy expenditure; EPOC, excess post-exercise $\mathrm{O}_{2}$ consumption; TEF, thermic effect of food.

-Ainsworth et al. (1993)

$\uparrow 15 \%$ of net exercise EE (Bahr et al. 1987).

$\$$ Estimated as $20 \%$ of the TEF from $3150 \mathrm{~kJ}$ meal (Segal et al. 1985).

bas et al. 1985; Maresh et al. 1992). Following resistancetype exercise, or high-intensity exercise, it has been suggested that the magnitude of EPOC is substantial (Bahr et al. 1992; Melby et al. 1993). However, the intensity and duration of exercise used in these studies is probably impractical for the average individual. Resistance exercise may produce a greater EPOC than aerobic exercise (Gillette et al. 1994), although it is difficult to equate similar exercise bouts for these two types of activity. Thus, the increase in $24 \mathrm{~h} \mathrm{EE}$ that is due to EPOC in the average individual is likely to be small and to have minimal impact on weight loss or weight maintenance.

An interaction between exercise and TEF has also been pursued to determine if there is potentiation of TEF when preceded or followed by exercise. Results are equivocal, with some authors reporting an enhancement of TEF (Segal \& Gutin, 1983; Young et al. 1986) and others finding no effect (Dallosso \& James, 1984; Schutz et al. 1987). This lack of consistency is partly due to the poor reproducibility of both measures of TEF (Weststrate, 1993) and EPOC (Commerford et al. 1997). However, quantitatively, if exercise does potentiate TEF, the increase in $24 \mathrm{~h}$ EE resulting is probably very small (Segal et al. 1985).

Table 1 gives an estimate of the total EE that may result from a single bout of daily exercise (net exercise $\mathrm{EE}+\mathrm{EPOC}$ + potentiation of TEF). For individuals who are active for health reasons and/or to maintain or lose weight, the additional energy that may be expended over $1 \mathrm{~d}$ due to planned exercise probably ranges from 932 to $2237 \mathrm{~kJ} / \mathrm{d}$ depending on body weight and the duration and intensity of the moderate exercise.

\section{Chronic exercise training and energy expenditure}

As RMR constitutes a large proportion of $24 \mathrm{~h} E E$, an increase in RMR could increase daily EE. The major determinant of RMR is fat-free mass (FFM; Ravussin et al. 1986). Habitual exercise, therefore, could mediate an increase in RMR indirectly through an increase in FFM. Whether regular activity also has a direct stimulatory effect on RMR, i.e. increasing metabolic rate per unit FFM, is controversial.

\section{Longitudinal studies}

Most studies report that following a period of exercise training, in previously sedentary individuals, RMR is not significantly elevated (Poehlman et al. 1986; Bingham et al. 1989) unless there is a concurrent increase in FFM (Broeder et al. 1992; Campbell et al. 1994). Thus, if FFM is increased by exercise training, RMR can be increased. In this regard, resistance training has been shown to be more effective at increasing FFM (Ballor et al. 1988; Pratley et al. 1994; van Etten et al. 1997) compared with aerobic exercise (Bingham et al. 1989; Broeder et al. 1992), although significant increases in FFM have been observed with prolonged endurance training (Westerterp et al. 1994). The probable magnitude of this increase in RMR through changes in FFM is, however, small (approximately $5 \%$ of initial RMR) (Broeder et al. 1992).

\section{Cross-sectional studies}

Where trained individuals have a greater FFM relative to sedentary individuals, they not only have a higher RMR (Gilbert et al. 1991) but also a greater non-training $24 \mathrm{~h} \mathrm{EE}$ (Horton \& Geissler, 1994). Certain studies also report that trained subjects have a greater RMR, even relative to FFM, compared with their untrained counterparts (Tremblay et al. 1985; Poehlman et al. 1989). This suggests an increase in the metabolic activity of the FFM, at least for some time period, as a reduction in training leads to a decline in RMR (Tremblay et al. 1988; Herring et al. 1992). To explain the observation of a higher RMR per unit FFM in trained individuals, it has been suggested that the high state of energy flux (high EE and high energy intake) characteristic of trained subjects is required for an elevation in RMR to be observed (Goran et al. 1994; Bullough et al. 1995). However, this state of high energy flux appears to require an amount and intensity of exercise that is not practical for the average individual $(>5000 \mathrm{~kJ} / \mathrm{d})$. Consequently, for most individuals, the main effects of chronic exercise training on RMR are through any changes in FFM.

\section{Does habitual exercise significantly increase daily energy expenditure?}

Daily EE under free-living conditions can be measured using the doubly-labelled-water technique. Even in individuals who would not be considered trained athletes, $24 \mathrm{~h} \mathrm{EE}$ is increased in relation to the amount of total active leisure time (Livingstone et al. 1991; Haggarty et al. 1994). With the introduction of an exercise training programme, significant increases in $24 \mathrm{~h}$ EE have been reported (Blaak et al. 1992; Westerterp et al. 1992; Van Etten et al. 1997). Goran \& Poehlman (1992) observed no increase in $24 \mathrm{~h} \mathrm{EE}$ following training in elderly subjects due to a decline in non-training activity. This emphasizes the need to maintain other spontaneous activity when commencing an exercise 
programme for weight control, otherwise the beneficial effect of exercise on $24 \mathrm{~h}$ EE may be negated.

\section{Effect of exercise on fat oxidation}

During exercise, energy is mainly supplied from the utilization of carbohydrate and lipid fuels, with a much smaller contribution from protein (Gollnick, 1985; Hood \& Terjung, 1990). Energy production during sustained aerobic exercise is mainly derived from the oxidative metabolism of fat and carbohydrate. With high-intensity, intermittent exercise, and resistance exercise, there can be a large contribution of anaerobic metabolism to energy production which utilizes mainly carbohydrate (Saltin, 1973).

During aerobic exercise, as intensity increases, the contribution of fat to energy production decreases (Brooks \& Mercier, 1994). Once exercise stops, fat oxidation is increased during the post-exercise period (Quinn et al. 1994; Horton et al. 1995). In addition, increased fat oxidation at rest has been observed on the day following aerobic exercise (Weststrate et al. 1990; Calles-Escandon et al. 1996). Little information is available on daily rates of fat oxidation with aerobic exercise, although Goldberg et al. (1990) observed no difference in $24 \mathrm{~h}$ RQ with three different levels of aerobic activity. Daily measurements of nutrient oxidation by indirect calorimetry need to be viewed critically, as the measure will be affected both by the nutrient intake and state of energy balance of a subject, as well as the exercise intervention itself. Nevertheless, it appears that aerobic exercise can increase total fat oxidation as well as $24 \mathrm{~h} \mathrm{EE}$.

It has been strongly suggested that low-intensity aerobic activity is best for promoting fat oxidation. Although lower intensities of exercise utilize a higher proportion of fat as a fuel, relative to higher intensities, the absolute amount of fat oxidized may not be very different. This is illustrated for a $65 \mathrm{~kg}$ recreationally-active individual with a maximum $\mathrm{O}_{2}$ uptake of $40 \mathrm{ml} / \mathrm{kg}$ body weight per min exercising for $40 \mathrm{~min}$ at either $50 \%$ or $70 \%$ of their maximum $\mathrm{O}_{2}$ uptake (Table 2). The absolute fat oxidation is not very different between the two exercise intensities. In addition, the $438 \mathrm{~kJ}$ extra expended during exercise at $70 \%$ maximum $\mathrm{O}_{2}$ uptake needs to be compensated for post-exercise. If stored energy is oxidized, this is going to be derived mainly from fat and could lead to an additional $10 \mathrm{~g}$ fat oxidized $(75 \%$ energy from fat oxidation during rest). The greatest fat oxidation, for a given time period of activity, is achieved, therefore, by exercising at as high an intensity as can comfortably be maintained.

Table 2. Absolute amount of fat oxidized by a $65 \mathrm{~kg}$ recreationallyactive individual with a maximum oxygen uptake of $40 \mathrm{ml} / \mathrm{kg}$ body weight per min exercising for 40 min at either $50 \%$ or $70 \%$ of their maximum oxygen uptake

\begin{tabular}{lccrrr}
\hline & & & \multicolumn{2}{c}{ Fat oxidized } \\
\cline { 5 - 6 } $\begin{array}{l}\text { \% Maximum } \\
\mathrm{O}_{2} \text { uptake }\end{array}$ & $\begin{array}{c}\text { Total energy } \\
\text { expended }(\mathrm{kJ})\end{array}$ & $\begin{array}{c}\text { \% Energy from } \\
\text { fat oxidation }\end{array}$ & $\mathrm{kJ}$ & $\mathrm{g}$ \\
\hline 50 & 1092 & 50 & 546 & $16 \cdot 3$ \\
70 & 1530 & 30 & 459 & 13.7 \\
Difference & 438 & & 87 & $2 \cdot 6$ \\
\hline
\end{tabular}

The exact effects of resistance or very-high-intensity intermittent exercise on nutrient oxidation during and postexercise is difficult to determine accurately. This is due to the anaerobic contribution to energy production during these types of activities, leading to inaccuracies in the indirect calorimetry calculations of nutrient oxidation (Brooks \& Fahey, 1984). During exercise, non-metabolic $\mathrm{CO}_{2}$ production can occur leading to $\mathrm{RQ}$ of $>1.0$ (Broeder et al. 1992). In the post-exercise period, there is $\mathrm{CO}_{2}$ retention as the bicarbonate pool is replenished and this can produce $R Q<0.7$. Observations on short-term nutrient oxidation with these types of exercise, therefore, need to be viewed critically and should be excluded from longer-term measurements (e.g. 24 h). However, well beyond the time of resistance or high-intensity exercise, reports are inconsistent as to whether fat oxidation is increased (Melby et al. 1993) or unchanged (Broeder et al. 1992; Treuth et al. 1996).

\section{Chronic exercise training effects on fuel utilization}

Adaptations in skeletal muscle following aerobic exercise training contribute to the increased ability to utilize lipid as a fuel during exercise (Hurley et al. 1986; Kiens et al. 1993). These changes include an increase in the proportion of oxidative muscle fibres, an increase in the muscle initochondrial content and an increase in the activity of various enzymes involved in oxidative metabolism (Holloszy \& Coyle, 1984). Aerobic exercise training also leads to an increased sensitivity of adipose tissue to the lipolytic action of catecholamines (Depres et al. 1984). This increases the ability to mobilize lipid. Resistance exercise and high-intensity exercise training tend to increase the number of glycolytic muscle fibres (Saltin, 1973) which may be less favourable to lipid oxidation. It could be argued, therefore, that aerobic training, rather than resistance and/or high-intensity exercise training, may be best for creating a metabolic environment geared towards fat utilization and decreasing fat mass.

Even at rest, increased fat oxidation has been observed following a period of aerobic exercise training (Poehlman \& Danforth, 1991; Poehlman et al. 1994) and in trained compared with untrained individuals (Tremblay et al. 1992; Romijn et al. 1993). Part of this effect of chronic training on resting fat oxidation may be due to the previous exercise bout (Calles-Escandon \& Driscoll, 1994). Resistance exercise training does not appear to increase fat oxidation at rest (Ryan et al. 1995; Toth \& Poehlman, 1995). Treuth et al. (1995) reported a lower $24 \mathrm{~h}$ and resting RQ on a nonexercise day following a strength training programme, but subjects were also in greater negative energy balance during the post-training measurement, which would also lower RQ. Consequently, the effects of resistance exercise training on chronic fat oxidation need further clarification.

\section{The impact of exercise alone on weight loss}

Although exercise can increase $24 \mathrm{~h} \mathrm{EE}$ in individuals for whom the goal is weight loss, the energy deficit created by exercise alone $(1148-2475 \mathrm{~kJ} / \mathrm{d})$ is small relative to the 
amount of body energy they need to lose (approximately $31130 \mathrm{~kJ} / \mathrm{kg}$ fat tissue). Even in theory, therefore, exercise alone would be expected to produce a very slow rate of weight loss. Not surprisingly, the effectiveness of exercise (aerobic and/or resistance) at decreasing body weight has been shown to be limited, with the magnitude of weight loss averaging $0.08-0.12 \mathrm{~kg} /$ week in men and women (Epstein \& Wing, 1980; Garrow \& Summerbell, 1995; Wilmore, 1995). Such a slow rate of weight loss is likely to be discouraging for an individual.

In general, exercise does have favourable effects on body composition (Wilmore, 1995). Aerobic exercise can significantly decrease fat mass (Bouchard et al. 1990; Westerterp et al. 1994), whereas resistance exercise appears to be less effective (Ballor et al. 1988; Broeder et al. 1992). This is probably due to the greater promotion of fat oxidation by aerobic $v$. resistance exercise. As previously discussed, resistance exercise can increase FFM, more so than aerobic activity, but this may lead to an even slower rate of weight loss. Exercise, therefore, can promote maintenance of a lower relative fat mass irrespective of degree of weight loss. However, exercise alone is of limited use as a primary treatment for obesity.

\section{The impact of exercise plus dietary restriction on weight loss}

Dietary restriction alone can produce a much greater daily energy deficit than exercise. Much research, therefore, has focused on the effect of dietary restriction with and without exercise on weight loss. The rationale behind this is first, that the exercise may increase the rapidity and degree of weight loss due to the creation of a greater energy deficit. Second, exercise may reduce the decline in FFM that occurs with weight reduction but increase fat loss. The lesser reduction in FFM would help decrease the fall in RMR and diminish the decline in energy requirements that results from a decreased body weight. Finally, exercise may help maintain better dietary compliance.

For weight loss alone, the majority of data suggests that this is not significantly increased when regular exercise is combined with an energy-restricted diet (Bogardus et al. 1984; Van Dale et al. 1987; Ballor et al. 1988; Heymsfield et al. 1989; Svendsen et al. 1993). Exercise, however, does have favourable effects on the composition of the weight that is lost. Garrow \& Summerbell (1995), in a metaanalysis of diet and diet plus exercise studies, reported that for a given weight loss, active men and women on a lowenergy diet had a lesser decrease in FFM than their sedentary counterparts ( 41 and $23 \%$ less respectively). Aerobic exercise also increases fat loss relative to diet alone (Heymsfield et al. 1989; Racette et al. 1995), whereas resistance exercise, in combination with dietary restriction, better maintains FFM (Ballor \& Keesey, 1991; Ryan et al. 1995). Although in theory it may be predicted that a combination of aerobic and resistance exercise would lead to better maintenance of FFM during dietary restriction and greater loss of body fat, this has not generally been found (Donnelly et al. 1991; Sweeney et al. 1993). Where a greater maintenance of FFM occurs with diet plus exercise compared with diet alone, the decline in RMR is reduced in proportion to the change in FFM (Kiem et al. 1990; Ryan et al. 1995).

Exercise may also improve adherence to an energyrestricted diet. Racette et al. (1995) reported that subjects who participated in a diet plus exercise programme lost more weight than the diet-only group due to a greater energy deficit resulting from both the daily exercise and better dietary compliance. In conclusion, therefore, exercise has beneficial effects on weight loss with dietary restriction mainly due to favourable effects on body composition changes and it may also improve dietary compliance. However, exercise appears not to increase the extent or rapidity of weight reduction.

\section{Effect of exercise on weight maintenance after weight reduction}

One of the major issues in the treatment of obesity is the long-term maintenance of weight loss. Successful weight reduction is not that difficult to achieve, but it is well established that weight regain occurs in most individuals (NIH, Technology Assessment Conference Panel, 1992). In a review of studies addressing long-term weight maintenance, Pronk \& Wing (1994) reported that individuals who were most successful at maintaining weight loss had incorporated regular exercise into their lifestyle. This was observed despite a large variation in the types of populations studied, and diet and exercise interventions used. Exercise, therefore, appears to be important in the post-obese individual for prevention of weight regain.

\section{How does exercise enable a more appropriate regulation of energy balance?}

Habitual, planned exercise has been shown to play a role in the maintenance of an appropriate body weight and body composition and to be beneficial in weight loss. Most of the present review has focused on how this may be mediated by the metabolic effects of physical activity, specifically in relation to $\mathrm{EE}$ and fat oxidation. However, the metabolic effects of exercise may also affect behaviour. With respect to food intake, physical activity appears to facilitate appropriate regulation of energy balance. Classically, this was shown by Mayer et al. (1954), who demonstrated that when animals exercised below or above a certain level they inappropriately adjusted their food intake to match EE such that weight gain and weight loss occurred respectively. In addition, there may be metabolic effects of exercise that determine subsequent exercise behaviour and why certain individuals are more inclined to exercise than others. In the future, elucidation of the link between exercise metabolism and behaviour may help in the design of exercise programmes that offer the most benefit with respect to the control of food intake and maintenance of an active lifestyle. This may then help in the long-term control of body weight and energy balance. 


\section{References}

Ainsworth BE, Haskell BL, Leon AS, Jacobs DR, Montoye HJ, Sallis JF \& Paffenberger RS (1993) Compendium of physical activities: classification of energy costs of human physical activities. Medicine and Science in Sports and Exercise 25, 7180.

Bahr R, Gronnerod O \& Sejersted OM (1992) Effect of supramaximal exercise on excess postexercise $\mathrm{O}_{2}$ consumption. Medicine and Science in Sports and Exercise 24, 66-71.

Bahr R, Ingnes I, Vaage O, Sejersted OM \& Newsholme EA (1987) Effect of duration of exercise on excess postexercise $\mathrm{O}_{2}$ consumption. Journal of Applied Physiology 62, 485-490.

Ballor DL, Katch VL, Becque MD \& Marks CR (1988) Resistance weight training during caloric restriction enhances lean body weight maintenance. American Journal of Clinical Nutrition 47, 19-25.

Ballor DL \& Keesey RE (1991) A meta-analysis of the factors affecting exercise-induced changes in body mass, fat mass and fat-free mass in males and females. International Journal of Obesity 15, 717-726.

Bingham SA, Goldberg GR, Coward WA, Prentice AM \& Cummings JH (1989) The effect of exercise and improved physical fitness on basal metabolic rate. British Journal of Nutrition 61, 155-173.

Blaak EE, Westerterp KR, Bar-Or O, Wouters LJM \& Saris WHM (1992) Total energy expenditure and spontaneous activity in relation to training in obese boys. American Journal of Clinical Nutrition 55, 777-782.

Bogardus C, Ravussin E, Robbins DC, Wolfe RR, Horton ES \& Sims EAH (1984) Effects of physical training and diet therapy on carbohydrate metabolism in patients with glucose intolerance and non-insulin-dependent diabetes mellitus. Diabetes 33, 311-318.

Bouchard C, Tremblay A, Nadeau A, Dussault J, Després JP, Theriault G, Lupien PJ, Serresse O, Boulay MR \& Fourniet G (1990) Long-term exercise training with constant energy intake. 1: Effect on body composition and selected metabolic variables. International Journal of Obesity 14, 57-73.

Broeder CE, Burrhus KA, Svanevik LS \& Wilmore JH (1992) The effects of either high-intensity resistance or endurance training on resting metabolic rate. American Journal of Clinical Nutrition 55, 802-810.

Brooks GA \& Fahey TD (1984) Exercise Physiology: Human Bioenergetics and Its Applications. New York: John Wiley and Sons.

Brooks GA \& Mercier J (1994) Balance of carbohydrate and lipid utilization during exercise: The 'crossover' concept. Joumal of Applied Physiology 76, 2253-2261.

Brouns F, Saris WHM, Stoecken J, Beckers E, Thijssen R, Rehrer NJ \& Ten Hoor F (1989) Eating, drinking, and cycling. A controlled Tour de France simulation study, Part I. International Journal of Sports Medicine 10, S32-S40.

Brownell KD \& Wadden TA (1992) Etiology and treatment of obesity: understanding a serious, prevalent, and refractory problem. Journal of Consulting and Clinical Psychology 60, 505-517.

Bullough RC, Gillette CA, Harris MA \& Melby CL (1995) Interaction of acute changes in exercise energy expenditure and energy intake on resting metabolic rate. American Journal of Clinical Nutrition 61, 473-481.

Calles-Escandon J \& Driscoll P (1994) Free fatty acid metabolism in aerobically fit individuals. Journal of Applied Physiology 77, 2374-2379.

Calles-Escandon J, Goran MI, O'Connell M, Nair KS \& Danforth E (1996) Exercise increases fat oxidation at rest unrelated to changes in energy balance or lipolysis. American Journal of Physiology 270, E1009-E1014.
Campbell WW, Crim, MC, Young VR \& Evans WJ (1994) Increased energy requirements and changes in body composition with resistance training in older adults. American Journal of Clinical Nutrition 60, 167-175.

Cannon G \& Einzig H (1984) Dieting Makes You Fat. London: Sphere Books Ltd.

Commerford SR, Cordain L \& Melby CL (1997) Reliability of the measurement of post-exercise oxygen consumption following two identically controlled cycling bouts. Medicine and Science in Sports and Exercise 29, S195.

Dallosso HM \& James WPT (1984) Whole-body calorimetry studies in adult man 2. The interaction of exercise and overfeeding on the thermic effect of a meal. British Journal of Nutrition 52, 65-72.

Danforth E Jr (1985) Diet and obesity. American Journal of Clinical Nutrition 41, 1132-1145.

Despres JP, Bouchard C, Savard R, Tremblay A, Marcotte M \& Theriault G (1984) The effect of a 20 -week endurance training program on adipose-tissue morphology and lipolysis in men and women. Metabolism 33, 235-239.

Donnelly JE, Pronk NP, Jacobsen DJ, Pronk SJ \& Jakicic JM (1991) Effects of a very-low-calorie diet and physical-training regimens on body composition and resting metabolic rate in obese females. American Journal of Clinical Nutrition 54, 5661.

Epstein LH \& Wing RR (1980) Aerobic exercise and weight. Addictive Behaviors 5, 371-388.

Flatt JP (1987) Dietary fat, carbohydrate balance, and weight maintenance: effects of exercise. American Journal of Clinical Nutrition 45, 296-306.

Freedman-Akabas S, Colt E, Kissileff HR \& Pi-Sunyer FX (1985) Lack of sustained increase in $\mathrm{VO}_{2}$ following exercise in fit and unfit subjects. American Journal of Clinical Nutrition 41, 545549.

Gaesser GA \& Brooks GA (1984) Metabolic bases of excess postexercise oxygen consumption: a review. Medicine and Science in Sports and Exercise 16, 29-43.

Garrow JS \& Summerbell CD (1995) Meta-analysis: effect of exercise, with or without dieting, on body composition of overweight subjects. European Journal of Clinical Nutrition 49, $1-10$.

Gilbert JA, Misner JE, Boileau RA, Ji L \& Slaughter MH (1991) Lower thermic effect of a meal post-exercise in aerobically trained and resistance-trained subjects. Medicine and Science in Sports and Exercise 23, 825-830.

Gillette CA, Bullough RC \& Melby CL (1994) Post-exercise energy expenditure in response to acute aerobic or resistive exercise. International Joumal of Sport Nutrition 4, 347-360.

Goldberg GR, Prentice AM, Davies HL \& Murgatroyd PR (1990) Residual effects of graded exercise on metabolic rate. European Journal of Clinical Nutrition 44, 99-105.

Gollnick PD (1985) Metabolism of substrates: energy substrate metabolism during exercise as modified by training. Federation Proceedings 44, 353-357.

Goran MI, Calles-Escandon J, Poehlman ET, O'Connell M \& Danforth E Jr (1994) Effects of increased energy intake and/or physical activity on energy expenditure in young healthy men. Journal of Applied Physiology 77, 366-372.

Goran MI \& Poehlman ET (1992) Total energy expenditure and energy requirements in healthy elderly persons. Metabolism 41 , 744-753.

Gore CJ \& Withers RT (1990) Effect of exercise intensity and duration on postexercise metabolism. Joumal of Applied Physiology 68, 2362-2368.

Griffiths M, Payne PR, Stunkard AJ, Rivers JPW \& Cox M (1990) Metabolic rate and physical development in children at risk of obesity. Lancet 336, 76-78. 
Haggerty P, McNeill G, Abu Manneh MK, Davidson L, Milne E, Duncan G \& Ashton J (1994) The influence of exercise on the energy requirements of adult males in the UK. British Journal of Nutrition 72, 799-813.

Herring JL, Molé PA, Meredith CN \& Stern JS (1992) Effect of suspending exercise training on resting metabolic rate in women. Medicine and Science in Sports and Exercise 24, 5965 .

Heymsfield SB, Casper K, Hearn J \& Guy D (1989) Rate of weight loss during underfeeding: Relation to level of physical activity. Metabolism 38, 215-223.

Hill JO, Pagliassotti MJ \& Peters JC (1994) Non-genetic determinants of obesity and body fat topography. In Genetic Determinants of Obesity, pp. 35-48 [C Bouchard, editor]. Boca Raton, FL: CRC Press Inc.

Holloszy JO \& Coyle EF (1984) Adaptations of skeletal muscle to endurance exercise and their metabolic consequences. Journal of Applied Physiology 56, 831-838.

Hood DA \& Terjung RL (1990) Amino acid metabolism during exercise and following endurance training. Sports Medicine 9 , $23-35$.

Horton TJ, Drougas HJ, Sharp TA, Martinez LR, Reed GW \& Hill JO (1994) Energy balance in endurance-trained female cyclists and untrained controls. Journal of Applied Physiology 76, 1937-1945.

Horton TJ \& Geissler CA (1994) Effect of habitual exercise on daily energy expenditure and metabolic rate during standardized activity. American Journal of Clinical Nutrition 59, 13 19.

Horton TJ, Pagliassotti MJ, Schaffer S, Hobbs K \& Hill JO (1995) Gender and training comparison of fat and carbohydrate oxidation during and following endurance exercise. Obesity Research 3, 346S.

Hurley BF, Nemeth PM, Martin WH, Hagberg JM, Dalsky GP \& Holloszy JO (1986) Muscle triglyceride utilization during exercise: training effect. Joumal of Applied Physiology 60 , 562-567.

James WPT (1995) A public health approach to the problem of obesity. International Journal of Obesity and Related Metabolic Disorders 19, S37-S45.

Kiem NL, Barbieri TF, Van Loan MD \& Anderson BL (1990) Energy expenditure and physical performance in overweight women: response to training with and without caloric restriction. Metabolism 39, 651-658.

Kiens B, Essen-Gustavsson B, Christensen NJ \& Saltin B (1993) Skeletal muscle substrate utilization during submaximal exercise in man: Effect of endurance training. Journal of Physiology 469, 459-478.

Livingstone MBE, Strain JJ, Prentice AM, Coward WA, Nevin GB, Barker ME, Hickey RJ, McKenna PG \& Whitehead RG (1991) Potential contribution of leisure activity to the energy expenditure patterns of sedentary populations. British Journal of Nutrition 65, 145-155.

Maresh CM, Abraham A, De Souza MJ, Deschenes MR, Kraemer WJ, Armstrong LE, Maguire MS, Gaberee CL \& Hoffman JR (1992) Oxygen consumption following exercise of moderate intensity and duration. European Journal of Applied Physiology 65, 421-426.

Mayer J, Marshall NB, Vitale JJ, Christensen JH, Mashayelchi MB \& Stare FJ (1954) Exercise, food intake and body weight in normal rats and genetically obese adult rats. American Journal of Physiology 177, 544-548.

Melby C, Scholl C, Edwards G \& Bullough R (1993) Effect of acute resistance exercise on postexercise energy expenditure and resting metabolic rate. Journal of Applied Physiology 75, 1847-1853.
NIH Technology Assessment Conference Panel (1992) Methods for voluntary weight loss and control. Annals of Internal Medicine 116, 942-949.

Poehlman ET \& Danforth E Jr (1991) Endurance training increases metabolic rate and norepinephrine appearance rate in older individuals. American Journal of Physiology 261, E233-E239.

Poehlman ET, Gardner AW, Arciero PJ, Goran MI \& CallesEscandon $J$ (1994) Effects of endurance training on total fat oxidation in elderly persons. Journal of Applied Physiology 76, 2281-2287.

Poehlman ET, Melby CL, Badylak SF \& Calles J (1989) Aerobic fitness and resting energy expenditure in young adult males. Metabolism 38, 85-90.

Poehlman ET, Tremblay A, Nadeau A, Dussault J, Theriault G \& Bouchard C (1986) Heredity and changes in hormones and metabolic rates with short-term training. American Journal of Physiology 250, E711-E717.

Pratley R, Nicklas B, Rubin M, Miller J, Smith A, Smith M, Hurley B \& Goldberg A (1994) Strength training increases resting metabolic rate and norepinephrine levels in healthy 50 to 65-yr-old men. Journal of Applied Physiology 76, 133-137.

Pronk NP \& Wing RR (1994) Physical activity and long-term maintenance of weight loss. Obesity Research 2, 587-600.

Quinn TJ, Vroman NB \& Kertzer R (1994) Postexercise oxygen consumption in trained females: Effect of exercise duration. Medicine and Science in Sports and Exercise 26, 908-913.

Racette SB, Schoeller DA, Kushner RF \& Neil KM (1995) Exercise enhances dietary compliance during moderate energy restriction in obese women. American Journal of Clinical Nutrition 62, 345-349.

Ravussin E, Lillioja S, Anderson TE, Christin L \& Bogardus C (1986) Determinants of 24-hour energy expenditure in man. Methods and results using a respiratory chamber. Journal of Clinical Investigation 78, 1568-1578.

Roberts SB (1995) Abnormalities of energy expenditure and the development of obesity. Obesity Research 3, 155s-164s.

Roberts SB, Savage J, Coward WA, Chew B \& Lucas A (1988) Energy expenditure and intake in infants born to lean and overweight mothers. New England Journal of Medicine 318, 461-466.

Romijn JA, Klein S, Coyle EF, Sidossis L \& Wolfe RR (1993) Strenuous endurance training increases lipolysis and triglyceride-fatty acid cycling at rest. Journal of Applied Physiology 75 , 108-113.

Ryan AS, Nicklas BJ \& Elahi D (1996) A cross-sectional study on body composition and energy expenditure in women athletes during aging. American Journal of Physiology 271, E916E921.

Ryan AS, Pratley RE, Elahi D \& Goldberg AP (1995) Resistive training increases fat-free mass and maintains RMR despite weight loss in postmenopausal women. Journal of Applied Physiology 79, 818-823.

Saltin B (1973) Metabolic fundamentals in exercise. Medicine and Science in Sports and Exercise 5, 137-146.

Schulz LO, Alger S, Harper I, Wilmore JH \& Ravussin E (1992) Energy expenditure of elite female runners measured by respiratory chamber and doubly labeled water. Journal of Applied Physiology 72, 23-28.

Schulz LO \& Schoeller DA (1994) A compilation of total daily energy expenditures and body weights in healthy adults. American Journal of Clinical Nutrition 60, 676-681.

Schultz Y, Bessard T \& Jequier E (1987) Exercise and postprandial thermogenesis in obese women before and after weight loss. American Journal of Clinical Nutrition 45, 1424 1432. 
Segal KR \& Gutin B (1983) Thermic effects of food and exercise in lean and obese women. Metabolism 32, 581-589.

Segal KR, Gutin B, Nyman AM \& Pi-Sunyer FX (1985) Thermic effect of food at rest, during exercise and after exercise in lean and obese men of similar body weight. Journal of Clinical Investigation 76, 1107-1112.

Svendsen OL, Hassager C \& Christiansen C (1993) Effect of an energy-restrictive diet, with or without exercise, on lean tissue mass, resting metabolic rate, cardiovascular risk factors, and bone in overweight postmenopausal women. American Journal of Medicine 95, 131-140.

Sweeney ME, Hill JO, Heller PA, Baney R \& DiGirolamo M (1993) Severe vs moderate energy restriction with and without exercise in the treatment of obesity: Efficiency of weight loss. American Journal of Clinical Nutrition 57, 127-134.

Toth MJ \& Poehlman ET (1995) Resting metabolic rate and cardiovascular disease risk in resistance- and aerobic-trained middle-aged women. International Journal of Obesity 19, 691698.

Tremblay A, Coveney S, Després JP, Nadeau A \& Prud'Homme D (1992) Increased resting metabolic rate and lipid oxidation in exercise-trained individuals: Evidence for a role of $\beta$-adrenergic stimulation. Canadian Journal of Physiology and Pharmacology 70, 1342-1347.

Tremblay A, Fontaine E \& Nadeau A (1985) Contribution of postexercise increment in glucose storage to variations in glucose-induced thermogenesis in endurance athletes. Canadian Journal of Physiology and Pharmacology 63, 1165-1169.

Tremblay A, Nadeau A, Fournier G \& Bouchard C (1988) Effect of a three-day interruption of exercise-training on resting metabolic rate and glucose-induced thermogenesis in trained individuals. International Journal of Obesity 12, 163-168.

Treuth MS, Hunter GS, Weinsier RL \& Kell SH (1995) Energy expenditure and substrate utilization in older women after strength training: 24-h calorimeter results. Journal of Applied Physiology 78, 2140-2146.
Treuth MS, Hunter GS \& Williams M (1996) Effects of exercise intensity on 24-h energy expenditure and substrate oxidation. Medicine and Science in Sports and Exercise 28, 1138-1143.

Van Dale D, Saris WHM, Schoffelen PFM \& Ten Hoor F (1987) Does exercise give an additional effect in weight reduction regimens? International Journal of Obesity 11, 367-375.

Van Etten LMLA, Westerterp KR, Verstappen FTJ, Boon BJN \& Saris WHM (1997) Effect of an 18-wk weight-training program on energy expenditure and physical activity. Journal of Applied Physiology 82, 298-304.

Van Itallie TB (1996) Prevalence of obesity. Endocrinology and Metabolism Clinic of North America 25, 887-905.

Westerterp KR, Meijer GAL, Janssen EME, Saris WHM \& Ten Hoor F (1992) Long-term effect of physical activity on energy balance and body composition. British Journal of Nutrition $\mathbf{6 8}$, 21-30.

Westerterp KR, Meijer GAL, Schoffelen P \& Janssen EME (1994) Body mass, body composition and sleeping metabolic rate before, during and after endurance training. European Joumal of Applied Physiology 69, 203-208.

Weststrate JA (1993) Resting metabolic rate and diet-induced thermogenesis: a methodological reappraisal. American Journal of Clinical Nutrition 58, 592-601.

Weststrate JA, Weys P, Poortvliet E, Deurenberg P \& Hautvast JGAJ (1990) Lack of a systematic sustained effect of prolonged exercise bouts on resting metabolic rate in fasting subjects. European Journal of Clinical Nutrition 44, 91-97.

Williamson DF, Madans J, Anda RF, Kleinman JC, Kahn HS \& Buyers T (1993) Recreational physical activity and ten-year weight change in a US national cohort. International Journal of Obesity 17, 279-286.

Wilmore JH (1995) Variations in physical activity habits and body composition. International Journal of Obesity 19, S113-S116.

Young JC, Treadway JL, Balon TW, Gavras HP \& Ruderman NB (1986) Prior exercise potentiates the thermic effect of a carbohydrate load. Metabolism 35, 1048-1053. 